\title{
Contraception and immunocastration vaccines. Use in veterinary medicine
}

\author{
Vacunas anticonceptivas y para inmunocastración. Su aplicación en la \\ Medicina Veterinaria.
}

Campal-Espinosa AC, Junco BJ, Fuentes AF, Calzada AL, Bover CA. Contraception and immunocastration vaccines. Use in veterinary medicine. Rev Colombiana Cienc Anim. Recia. 2020; 12(2):e760. DOI: https://doi.org/10.24188/recia.v12.n2.2020.760

Universidad de Sucre, Colombia

Los autores permiten a RECIA reimprimir el material publicado en él. En caso de que un autor quiera traducir o usar una publicación parcial o completa de nuestro Diario, el autor debe obtener un permiso por escrito del editor de la revista.

Copyright (C) 2020. El (los) autor (es), Revista Colombiana de Ciencia Animal - RECIA. 2020. Este es un artículo de acceso abierto distribuido bajo los términos de Creative Commons Attribution 4.0 (https://creativecommons.org/licenses/by-nc-sa/4.0/), El uso, distribución o reproducción está permitido, siempre que se acrediten al autor original y al propietario del copyright y que se cite la publicación original en esta revista, de acuerdo con la práctica académica aceptada. No se permite el uso, distribución o reproducción que no cumpla con estos términos.

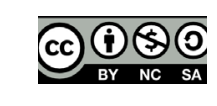




\title{
Contraception and immunocastration vaccines. Use in veterinary medicine
}

\author{
Vacunas anticonceptivas y para inmunocastración. Su aplicación en la Medicina \\ Veterinaria
}

Ana Cristina Campal-Espinosa. Ph.D.

DOI: https://doi.org/10.24188/recia.v12.n2.2020.760

Center of Genetic Engineering and Biotechnology. Research-Development

Department. Biomedical Research Group. Camagüey, Cuba.

*ana.campal@cigb.edu.cu

(iD) https://orcid.org/0000-0001-5488-3767

Jesús Arturo Junco B. Ph.D.

Center of Genetic Engineering and Biotechnology. Research-Development Department. Biomedical Research Group. Camagüey, Cuba.

jesus.junco@cigb.edu.cu

(iD) https://orcid.org/0000-0002-9391-3102

Franklin Fuentes A. M.Sc;

Center of Genetic Engineering and Biotechnology. Research-Development

Department. Biomedical Research Group. Camagüey, Cuba.

franklin.fuentes@cigb.edu.cu

(D) https://orcid.org/0000-0002-8350-0558

Lesvia Calzada A. B.Sc;

Center of Genetic Engineering and Biotechnology. Research-Development Department. Biomedical Research Group. Camagüey, Cuba.

lesvia.calzada@cigb.edu.cu

(iD) https://orcid.org/0000-0003-3662-2162

Ana Claudia Bover C. MD.

Eduardo Agramonte Piña Children's University Hospital. Immunology

Department. Camagüey, Cuba.

ana.bover@nauta.com.cu

(D) https://orcid.org/0000-0002-4126-9597

Recepción: 2 abril 2020

Aprobación: 25 junio 2019

Publicación: 3 julio 2020

\begin{abstract}
Globally, development and application of vaccines to control fertility in animals is growing relentlessly. Their productive benefits to animal management and welfare are corroborated, while improvement in public perception on their positive impact. This paper reviews current developments in this area, particularly, immunocastration vaccines, upon assessment of application results in recent years. Main targets of these vaccines are proteins of the zona pellucida, the structural proteins of spermatozoa as well as the sexual hormones. Various GnRH-based vaccines with proven effectiveness and efficiency for immunocastration of males and fertility control in females are commercially available today. However, issues like a reduction in the number of immunizations, achieving of increased immunogenicity, and the development new formulations to facilitate the application and release of vaccines in the wide diversity of the animal habitats and in the different conditions of animal husbandry, should be addressed. Fertility control relied on methods that guarantee productive efficiency and animal welfare is an incessant need of modern veterinary medicine practice.
\end{abstract}

Keywords: Contraception; GnRH; immunocastration; spermatozoa; vaccines; zona pellucida (NCI Term Browser, https://evs.nci.gov/ftp 1/NCI thesaurus). 


\section{RESUMEN}

A nivel mundial, el desarrollo y la aplicación de vacunas para controlar la fertilidad en los animales, está creciendo indeteniblemente. En los últimos años se han corroborado sus beneficios productivos para el manejo y el bienestar de los animales, lo que ha contribuido a mejorar la percepción pública sobre sus impactos. Este artículo revisa los avances obtenidos en este campo, en particular, las vacunas de inmunocastración, tras la evaluación de los resultados de su aplicación en los últimos años. Las principales dianas antigénicas de estas vacunas son las proteínas de la zona pelúcida, las proteínas estructurales de los espermatozoides y las hormonas sexuales. En la actualidad están disponibles en el mercado varias vacunas basadas en $\mathrm{GnRH}$, con eficacia y eficiencia comprobadas para la inmunocastración de los machos y el control de la fertilidad en las hembras. Sin embargo, los investigadores deberán resolver cuestiones como la reducción del número de inmunizaciones, el logro de una mayor inmunogenicidad y el desarrollo de nuevas formulaciones para facilitar la aplicación y liberación de estas vacunas en los diversos hábitats donde transcurre la vida animal y en las diferentes condiciones de la crianza ganadera. El control de la fertilidad basado en métodos que garantizan la eficiencia productiva y el bienestar animal es una necesidad incesante de la práctica moderna de la medicina veterinaria.

Palabras clave: Anticoncepción, GnRH, inmunocastración, espermatozoides, vacunas, zona pelúcida (NCI Term Browser, https://evs.nci.gov/ftp 1/NCI thesaurus).

\section{INTRODUCTION}

The development of effective fertility control methods in animals, especially mammals, is a priority of modern veterinary practice in face of growing need to guarantee animal welfare in every aspect. Livestock systems require the inhibition of male sexual development to shorten the fattening period and ensure proper organoleptic characteristics of meats to cope with market demands (1). Moreover, there is a need to prevent aggressiveness, undesired reproduction, and sexual behavior, which can cause difficulties during husbandry and damages to other animals, facilities, and pasture (2). In turn, the reproductive cycles of females should be controlled according to the goals of production, such as estrus synchronization for artificial insemination (3), anestrus control to regulate pregnancy intervals (4), or prevention of reproduction at the end of the productive cycle. For their part, pet owners and breeders demand of noninvasive, harmless and effective methods to control animal fertility and sexual behavior (5).

Traditionally, the solution to these problems has been male castration based on surgical, chemical, or physical methods and, in females, sexual segregation and ovariectomy. Small pets and animals also underwent surgical sterilization. These methods, however, interfere with animal welfare causing pain, stress, increased risk of infection, diseases, hemorrhagic disorders, and deaths. Their application is impossible in wild and non-stabled animals, and practices like hunting, intoxication, and even poisoning, are performed to control their populations. These inhumane and punishable procedures are unethical, and several animal welfare organizations demand their total elimination.

Consequently, a more tightened legal framework has been established seeking better animal protection. The European Union has banned surgical castration of $>7$-day-old male animals without anesthesia and analgesics $(6,7)$, but its final objective is to reach the phasing out of surgical castration (8).

In this context, immunization of males with gonadotropin-releasing hormone (GnRH) or immunocastration has occupied a leading place among researches in this field. Active vaccination against $\mathrm{GnRH}$, using hormone analogues or appropriate adjuvants, produces anti-GnRH antibody response capable of neutralizing the circulating hormone. The inability of the hormone to bind to its receptors in the pituitary suppresses the synthesis of gonadotropins, testosterone and inhibin B, causing infertility (9). Immunocastration has shown productive and animal health benefits. However, its wide use in livestock farming is hampered by the laboriousness that implies the application of immunization schemes in large livestock exploitations (10).

Thus, this paper examines the current state of research on fertility control, emphasizing in the area of immunocastration vaccines based on their promising results after application in recent years.

\section{DEVELOPMENT}

Today, the alternatives to control animal fertility include surgical castration with anesthesia and/or analgesics, sperm selection to generate gametes of a desired sex, extensive breeding of whole males (11), physical separation of animals 
of different sexes, hormonal ablation, and vaccines. In practice, surgical castration and vaccines have proven higher feasibility (12).

The vaccines to control fertility pursue two main goals: immunological contraception and immunocastration. The former prevents oocyte fertilization by sperm, or implantation of the fertilized egg through autoimmune response against components of the reproductive system, whereas sexual behavior and mating remain normal. In females, these approaches are useful to control invading, wild or free-living species (13). In the second, the purpose is to eliminate reproduction and sexual behavior in males and females, and it is more commonly used in livestock systems and pets (13). Several veterinary vaccines developed for both purposes, in different species, have been commercialized. (Table 1)

Table 1. Commercialized vaccines for fertility control and immunocastration.

\begin{tabular}{|c|c|c|c|c|}
\hline Vaccine & Supplier & Indication/Target species & Formulation & Doses \\
\hline ZonaStat-H & $\begin{array}{l}\text { Humane Society of the United } \\
\text { States, Washington, DC, USA }\end{array}$ & $\begin{array}{l}\text { FC in wildlife animals /feral } \\
\text { mares and donkeys }\end{array}$ & $\begin{array}{c}\text { 65 } \mu \mathrm{g}-100 \mu \mathrm{g} \text { Swine ZP proteins + Adjuvant } \\
\text { (modified Complete Freund Adjuvant mCFA) }\end{array}$ & $\begin{array}{l}2-4 \text { doses, at } 30 \text { days } \\
\text { intervals and annual } \\
\text { boosters }\end{array}$ \\
\hline ZonaStat-D & idem & idem/white-tail deer & Swine ZP proteins + mCFA & idem \\
\hline SpayVac & $\begin{array}{l}\text { ImmunoVaccine } \\
\text { Technologies }^{\mathrm{TM}} \text {, Halifax, Nova } \\
\text { Scotia, Canada }\end{array}$ & $\begin{array}{l}\text { idem/horses, donkey, seals, } \\
\text { deer }\end{array}$ & $\begin{array}{c}200 \mu \mathrm{g}-500 \mu \mathrm{g} \text { PZP protein capsulated in } \\
\text { liposome + mineral oil with Mycobacterium } \\
\text { avium (Adjuvac) }\end{array}$ & Single dose \\
\hline PZP-22 & $\begin{array}{l}\text { University of Iowa, School of } \\
\text { Pharmacy, Iowa City, USA }\end{array}$ & idem/mares, deer & $\begin{array}{l}\text { lactide-glycolide pellets containing } 65 \mu \mathrm{g} \\
\text { PZP for slow release }\end{array}$ & $\begin{array}{l}2 \text { doses at monthly } \\
\text { interval and annual } \\
\text { boosters }\end{array}$ \\
\hline Vaxstrate & $\begin{array}{l}\text { (Arthur Webster Pty Ltd, } \\
\text { Castle Hill, N.S.W.) }\end{array}$ & FC in bovine both sexes & $\begin{array}{c}1 \mathrm{mg} \text { GnRH analogue conjugated with } \\
\text { ovalbumin + 5\% DEAE Dextran and 50\% } \\
\text { water in mineral oil emulsion }\end{array}$ & $\begin{array}{l}2 \text { doses at least } 2 \text { weeks } \\
\text { apart }\end{array}$ \\
\hline Improvac $^{\circledR}$ & Zoetis $^{\mathrm{TM}}$ & $\begin{array}{l}\text { IC and prevention boar taint/ } \\
\text { swine }\end{array}$ & $\begin{array}{l}200 \mu \mathrm{g} \text { GnRH analog covalently linked to } \\
\text { diphtheria toxoid (GnRH-DT) + Adjuvant: } \\
\text { 300mg DEAE-Dextran (Advasure) }\end{array}$ & $\begin{array}{c}2 \text { doses at least } 4 \text { weeks } \\
\text { apart }\end{array}$ \\
\hline Bopriva $^{\circledR}$ & Zoetis $^{\mathrm{TM}}$ & IC, PSB/cattle & Similar to Improvac but with $400 \mu \mathrm{g}$ GnRH-DT & $\begin{array}{c}2 \text { doses at least } 3 \text { weeks } \\
\text { apart }\end{array}$ \\
\hline Gonacon $^{\mathrm{TM}}$ & $\begin{array}{l}\text { USDA/APHIS National Wildlife } \\
\text { Research Center, USA }\end{array}$ & $\begin{array}{l}\text { FC, CSB/deer, bison horses, } \\
\text { squirrels elk, prairie and feral } \\
\text { dogs, feral cat both sexes }\end{array}$ & $\begin{array}{c}200 \mu \mathrm{g}-3000 \mu \mathrm{g} \mathrm{GnRH} \text { (ten copies in } \\
\text { tandem) conjugated with keyhole-limpet } \\
\text { hemocyanin }(\mathrm{KLH})+\text { Adyuvac }\end{array}$ & Single dose \\
\hline Repro-BLOC ${ }^{\mathrm{TM}}$ & $\begin{array}{l}\text { Amplicon Vaccine LLC, } \\
\text { Pullman, WA, USA }\end{array}$ & $\begin{array}{c}\text { FC in heifers and elephants } \\
\text { and PCB and pathologies in } \\
\text { elephants }\end{array}$ & $\begin{array}{l}\text { 1mg-30 mg recombinant ovalbumin-LHRH-7 } \\
\text { fusion protein + IFA with a synthetic cytosine } \\
\text { guanine oligodeoxynucleotide }(\mathrm{CpG})\end{array}$ & $\begin{array}{l}\text { Priming dose and booster } \\
\text { injections, quarterly }\end{array}$ \\
\hline Equity & Zoetis & $\begin{array}{l}\text { Control of estrus or estrus- } \\
\text { related behavior in fillies and } \\
\text { mares and population control } \\
\text { in deer. }\end{array}$ & $\begin{array}{c}200 \mu \mathrm{g} \text { GnRH-DT + } 300 \mu \mathrm{g} \text { Iscomatrix } \\
\text { (Saponin Quil A + Cholesterol + } \\
\text { dipalmitoylphosphatidyl choline) }\end{array}$ & $\begin{array}{l}\text { Two doses } 4 \text { weeks apart } \\
\text { and booster vaccination } \\
\text { every } 3-6 \text { months }\end{array}$ \\
\hline
\end{tabular}

FC-fertility control, IC-Immunocastration, PSB-prevent sexual behavior

\section{Contraception using vaccines against spermatozoa- and egg-specific proteins}

The zona pellucida (ZP) contains 3 or 4 proteins, species, identified as ZP1, ZP2, ZP3, and ZP4, with various preservation degrees between the mammals (14), which are attractive targets for immunological contraception in females. These glycoproteins form a matrix surrounding the oocyte, and allow spermatozoa receptivity, the induction of the acrosomal exocytosis at the sperm-binding site, prevent polyspermy, and protect the fertilized oocyte during the initial stages of differentiation (15).

The ZP proteins used as heterologous vaccine antigens are obtained from natural sources or, and more recently, by recombinant DNA techniques or derived synthetic peptides. The anti-ZP antibodies generated by immunizations can block fertilization and/or folliculogenesis and inhibits ovulation as well as the normal development corpus luteum (15). 
Four vaccines against ZP are now available at the market (Table 1). The first one, ZonaStat-H, was approved by the US Environmental Protection Agency (EPA), in 2012. The second variant, ZonaStat-D was approved later, in 2017 (15). Both contains ZP-swine proteins obtained from natural sources and, require the application of several doses during the first year, and an annual booster to keep infertility in animals (15).

The third variant, Spayvac (Immunovaccine Technology Inc (IVT, Halifax, NS, Canada) contains lyophilized ZP proteins capsuled in liposomes (DepoVax), forming a water-in-oil emulsion, in Adjuvac (National Wildlife Research Center, USA). This platform known as Vaccimax (15) induces a very strong anti-ZP immunological response, a single-dose application has shown high, long lasting effectiveness (1-3 years) in gray seals, wild horses (16), dama dama, white-tailed deer (Odocoileus virginianus) (17), and other species.

Recently, PZP-22, another variant of this vaccine based on slow-released pellets, was approved (Table 1) (18). Upon administration to mares, the number of parturitions was reduced in 79\%. However, its efficacy is being studied, since only a 38\% reduction was achieved after the second application, the following year (18).

The main issue associated with these vaccines, is the irreversibility of infertility due to oophorotis and follicular atresia (19). Three additional factors limits its wider use: the species-specific glycosylation of ZP-proteins, the maintenance of estrus and mating rituals among the animals (20) and the extension of breeding season (21) limiting its use in livestock systems and in wildlife.

Despite the identification of about 10 target antigens: sperm-specific lactate dehydrogenase (LDH-C4) (22), sperm adhesion molecule SPAM-1 (PH-20) (23), fertilization antigen FA-1 (24), and others; the development of vaccines against sperm proteins has been a more complex endeavor. The goal is to produce antibodies that block the binding of sperm to the oocyte and its fertilization, to cause infertility in males during sperm production in the testicles and its maturation in the epididymis and in females, through interference of sperm-egg interaction in their reproductive tract and the preimplantation embryonic development (25).

LDH-C4 is an enzyme present in the testicles and sperm of birds and mammals, which takes part in energetic metabolism and sperm capacitation. In turn, SPAM-1 (24), is a glycoprotein associated to the plasmatic and internal acrosomal membranes of sperm which has hyaluronidase activity (12). Its function is to attach to the ovum and penetrate the cumulus (25). Their combination with cellular structural proteins $\beta$-actin and $\alpha$-tubulin homogenized with N-acetyl-muramyl-Lalanine-disoglutamine hydrate in the presence of CFA or IFA are part of a vaccine candidate used to control fertility in bitches. A phase-1 clinical trial in dogs showed serum antibodies response against surface proteins of spermatozoa LDH-C4 and PH-20, which caused infertility, but also maintained estrus. The authors considered that the presence of anti-actin, anti-PH-20, and anti-tubulin antibodies in the oviductal fluids inhibited capacitation, acrosomal reaction, and attachment of spermatozoa to the ovum, whereas the anti-LDH-C4 antibodies immobilized spermatozoa, inhibiting fertilization (26). The effectiveness of candidate should be evaluated in different species, since formulations based on protein LDH-C4 supplied to female macaques induced high specific antibody titers without causing infertility (27).

\section{Hormones as a targets for immunocontraception.}

The need to develop vaccines for fertility control in multiple species and in both sexes, have turn attention of researchers to sexual hormones: follicle stimulating hormone (FSH) and its receptor (FSHR), luteinizing hormone (LH), and gonadotropin releasing hormone $(\mathrm{GnRH})(28)$.

The LH-based vaccine candidates produce specific antibodies that induce azoospermia, suppress testicle function and testosterone production. However, they have been unsuccessful due to their weak immunogenicity and the alopecia and weight loss observed in immunized monkeys (28).

Among hormones and receptors of LH, FSH, the thyroid stimulating hormone (TSH), and chorionic gonadotropin (CG), there is a significant homology in the structures and amino acid sequences (29). Therefore, LH/FSH vaccination and its receptors can induce antibodies toward preserved regions of the homologous receptors interfering in their functions. The vaccination of non-human primates with ovine FSH led to a testicular dysfunction, oligozoospermia, high presence of abnormal spermatozoa in the semen, and infertility, with no decrease in the concentration of serum testosterone (30). However, FSH-deficient male mice have demonstrated to be fertile, despite of decrease in testicle size (30). The most promising results have been achieved with a candidate that requires of an initial immunization with recombinant FSHR, and re-immunizations with a recombinant peptide (32-44aa segment) derived from an immunodominant domain for B-cell recognition of the FSHR which caused infertility in mice without inducing changes or affecting the reproductive apparatus (31). 
Moreover, GnRH plays a key role in the regulation of fertility in mammals. It is a well-preserved hormone in vertebrates, which has three isoforms: GnRH-I, GnRH-II, and GnRH-III with different functions. Isoforms I and II induce gonadotropin secretion in mammals. GnRH-I is a decapeptide produced by a limited number of neurons in the hypothalamus, and transported by the hypothalamic-hypophyseal portal system to the anterior pituitary. Then, it binds to the gonadotropin receptors to stimulate LH and FSH secretion into the blood torrent. GnRH secretion through the neurons is pulsatile, thus guaranteeing cyclical production of FSH and LH (32).

The GnRH-based strategies to control fertility have included the utilization of antagonists and agonists of the hormone, GnRH-based peptide vaccines or their receptors, passive immunization, and destruction of receptors using the cytotoxinscoupled hormone. However, considering the scope of this review we will refer only to active GnRH-immunization.

Anti-GnRH vaccination includes the production of specific neutralizing antibodies of the endogenous hormone by suppressing the synthesis and secretion of gonadotropins in the pituitary, and consequently, of gonadal steroids, blocking gametogenesis and causing infertility in both sexes $(33,34,35)$.

In the 1980s and 90s, pioneer studies conducted to different mammal species proved that immunizations with native GnRH or analogues (GnRH-based peptides with punctual mutations in the $6^{\text {th }}$ position, particularly) conjugated, chemically, to epitopes or immunogenic proteins and administered in high doses in the proper adjuvant, led to an immunological response against the hormone capable of neutralizing it $(33,34)$. Consequently, testosterone was reduced to castration levels, along with gametogenesis arrest, atrophy of the reproductive apparatus, and prostate hypoplasia (35). These effects were reversible when immunization ceased (35). Nevertheless, the heterogeneity in the intensity of anti-GnRH immune response in animals, and the short duration of immunocastration showed the need for new formulations, dose studies, and more effective adjuvants.

Vaxtrate was the first commercial vaccine for immunocastration (Table 1); it was withdrawn from the market due to its low immunogenicity and adverse effects associated with the adjuvant (36). Today, more advanced GnRH based vaccines are being sold (Table 1). All were designed by conjugating the native or modified hormone with immunogenic proteins and epitopes capable of stimulating T-helper immune response (Th) and generate GnRH neutralizing antibodies using different adjuvants.

The most successful example, of a GnRH-based vaccine has been Improvac (Zoetis, United States) (Table 1) (37). For immunocastration two doses should be administered to pigs that will be slaughtered at 26 or 27 weeks; while three doses should be applied to those that will be slaughtered at older age. After the third dose, castration remains effective for 20 months. The immunocastrated animals have higher contents of lean meat, and larger carcasses than the surgically castrated animals (37). In experimental studies, Improvac has also shown positive results to delay puberty in males (38), whereas caused estrus inhibition in immunized females, along with decreased progesterone levels, and the ovarian and uterine atrophies (39).

Zoetis also has developed Bovipra, a vaccine for bovine castration (40). It is applied to 20- and 25-month-old bulls, resulting in very low testosterone levels for 12-16 weeks. Its application in breeds like Zebu bulls (Bus indicus) or their crossbreds, Holstein, Hereford, Charolais, and Brown Swiss, has produced 80\% effectiveness (41).

The most commonly adverse effects observed with both vaccines are pyrexia, transient pain, and swelling at the site of injection (42).

In countries like Brazil, where cattle undergo delayed castration (18-24 months old) to ensure high weight gains, immunocastration has replaced traditional castration to lower costs (1). Its main advantages are associated to prevention of myiasis and infections, improvements on feed conversion, stress reduction, stimulation of growth and weight increase, whereas there is an increment in lean meat contents by animal with a high quality for the industrial processing (1,40,41). Since castration takes place at older ages than in traditional livestock, these animals are superior anabolically, due to keeping high concentrations of anabolic hormones and growth hormones in the serum for a longer time (41).

GonaCon $^{\mathrm{TM}}$, is a vaccine (Table 1) conceived to control super populations of several wild mammal species (42). It is available at different peptide doses formulations, depending on the size of the species to be immunized: small animals received up to $400 \mu \mathrm{g}$, and large animals, up to $2 \mathrm{mg}$, intramuscularly. This vaccine has high safety profile and is $100 \%$ effective for a year, then this property vary among species, according to the results of clinical trials performed on squirrels, dogs, deer, felids, bisons, and others (42). 
No immunocastration and fertility control vaccine for ovine is commercially available (1), though anti-GnRH vaccines used in other species have been administered to male ovine, resulting in a reduction of aggressive behavior, mating odors, testosterone levels, and size of reproductive organs (43). An experiment conducted by Kiyma et al (44) in sheep, demonstrated that immunocastration lowered food conversion efficiency and the weight gain rate, when compared to intact animals.

In recent years, our research team has been working on the development a novel GnRH-based vaccine candidate for immunocastration in livestock systems. The originality of our approach lies in the combined use of two 27-amino acids size GnRH- based synthetic peptides(45). Based in previous studies (46), both peptides, in equivalent amounts (750 $\mu \mathrm{g}$ total), were adjuvated in Montanide ISA 51 VG (Seppic, France) and very small size proteoliposomes (VSSP). Formulation was conceived to induce Th1/Th2 immune responses, taking advantage of adjuvant's ability to produce a powerful antibody response and the VSSP's property to activate the innate immune system (47).

\section{Natural GnRH PEHWSYGLRPG \\ GnRHm1 - TT PEHWSYPLRPG GG QYIKANSKFIGITEL \\ TT - GnRHm1 QYIKANSKFIGITEL GG PEHWSYPLRPG}

Schematic representation of aminoacidic composition of the GnRH analogues peptides including in the vaccine candidate. Both composed by a GnRH-analog obtained by substituting the L-glycine (G) at sixth position in the native hormone by L-prolina (P) (red) fused through a Gly-Gly spacer to a Th epitope (aa 830-844) of the tetanus toxoid (TT) (blue) (47). In one instance, the immunogenic epitope was placed at the carboxyl-terminal end of GnRH (GnRHm1-TT) and in the other, the amino-terminal end (TT-GnRHm1).

The demonstration of the synergistic effect of both peptides on the production of anti-GnRH antibodies, hormonal ablation and immunocastration (Figure 1) as well as, contribution in the homogenization the anti-GnRH antibodies response and its associated biological effects, among all immunized animals were essential results of the proof of concept carried out with our vaccine candidate (48). On-going preclinical characterization trials might lead to a more innocuous vaccine causing highly effective and long lasting immunocastration.
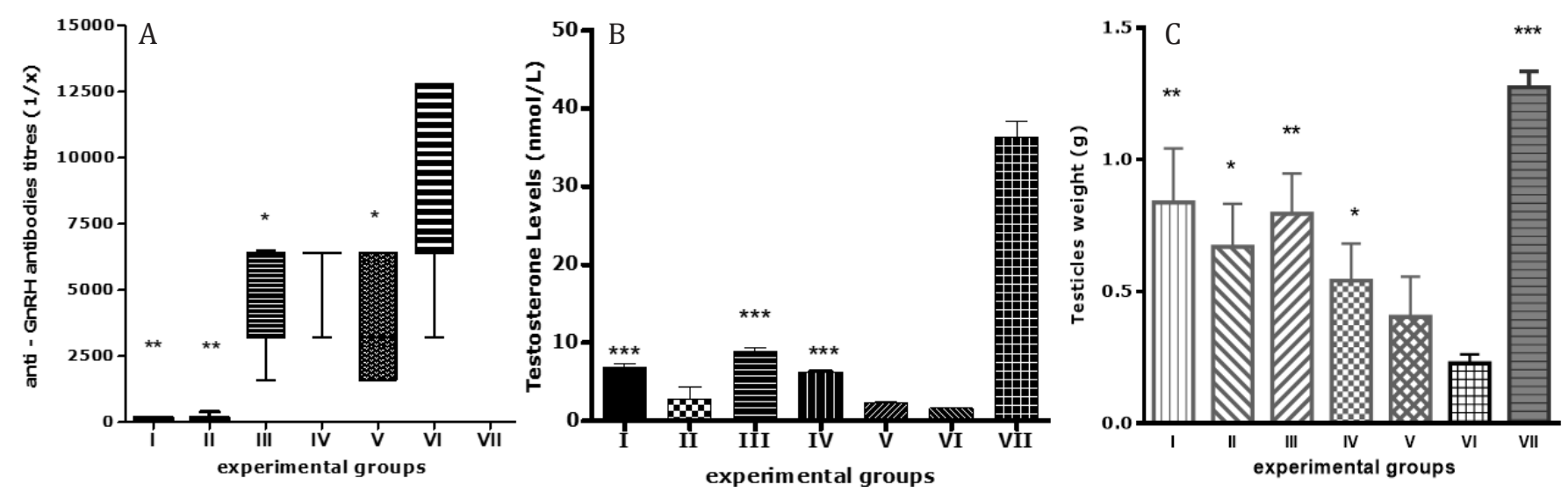

Figure 1. Biological effects 75 days after first immunization with TT-GnRH/GnRH-TT vaccine candidate. Male adult Copenhagen rats ( $n=7$ per group) received 4 immunizations, fortnightly with following combinations: I- GnRHm1-TT/Montanide ISA 51VG; II- GnRHm1-TT/ Montanide ISA 51VG/VSSP; III- TT-GnRHm1/Montanide ISA 51VG; IV- TT-GnRHm1/Montanide ISA 51VG/ VSSP; V- GnRHm1-TT/TT-GnRHm1/ Montanide ISA 51VG; VI- GnRHm1-TT/TT-GnRHm1/ Montanide ISA 51VG /VSSP; VIIPlacebo. In the graph is shown synergistic effect of immunization with both peptides (Groups V and VI) on increasing serum anti-GnRH antibodies titers (A) falling serum testosterone to castration levels (B) and the decreasing of testicles weight (C). The differences among average values of evaluated variables for each group respect to those in Group IV are represents by asterisks. Mann-Whitney test $(\mathrm{p}<0.05)$.

Undoubtedly, the use of GnRH-based vaccines in livestock systems benefits to animal welfare. However, stabling and the short time of life of the animals, hamper the assessment of the medium and long-term adverse events associated with these vaccines. In wildlife animals, anti-GnRH vaccination, has been related with changes in its muscular appearance and with the atrophy of some secondary sexual characters such as the elk or deer`s antlers and the scent-marking glands in capybaras (49). Hormonal ablation in gregarious animals affects both the structure of the herd and the social interaction 
between its members. It has been reported that immunocastrated feral horses (E. caballus), feed, rest and travel less (50). The loss of aggressiveness, dominance and hierarchy increasing the vulnerability of vaccinates respect to the rest of the males affecting drastically its survival in the wild.

\section{Long - term immunity and vaccine delivery systems: the two great research challenges in immunocontraception.}

There is consensus on the feasibility of oral and oral-nasal routes for immunization of different species in the most diverse habitats. However, such vaccines are complex to develop, since the peptides or proteins required should be resistant to low-pH degradation and the proteolytic enzymes present in the gastrointestinal tract (51). Moreover, problems related to poor oral absorption, low metabolic stability, and difficulty going through the biological membranes of these molecules, should be addressed (52). Additionally, the formulations must be highly stable to allow their administration mixed with meals and, to be released in the extreme environmental conditions proper to natural ecosystems, as well as, provide effective antigenic presentation through the Peyer's patches in the intestines. Several carrier or antigen-releasing systems have been designed in liquid and particulate formulations. These systems, in the form of emulsions, liposomes, microparticles, nanoparticles, or archeosomes (vesicles of polar liquids of halophilic archaebacteria), containing innate and adaptive immune system stimulating molecules, might be a solution to avoid adjuvant use, due to their capacity to enhance the immunological response.

Dendrimers or synthetic self-adjuvating lipopetides are another attractive alternative to develop oral vaccines. Newly developed dendrimers contain various GnRH copies attached to a lipid nucleus derived from lipid A, which is composed of 2-amino-d, l-hexadecanoic acid, and Th and B immunogenic epitopes. The immunization of mice with this molecule produced high anti-GnRH antibody responses, and the dendritic cells stimulation (53). This and other chemical modifications to peptides, like cyclization, glycosilation, and lipidation, are viable alternatives to modulate their physical and chemical properties and increase their bioavailability orally. Oral administration of glycosilated GnRH-analogue peptides to rats has demonstrated their metabolic stability, a capacity to penetrate the cell membranes through glucose transport systems, and high resistance to proteases and the acidic environment of the gastrointestinal system (54). However, the effects of these modifications on peptide immunogenicity should be evaluated.

Chitosan, a low molecular weight cationic polysaccharide, has also been used as adjuvant in a GnRH-based recombinant vaccine to control fertility by inducing long-lasting Th1/Th2 immune response in Balb/c mice of both sexes (55).

Adjuvation with immunostimulating complexes (ISCOMs) (lipophilic saponins that form a box-like structure with the antigen) is another alternative for GnRH-KLH immunization. Preclinical studies shown the induction of elevated antiGnRH response in immunized mice (56).

Recently, high molecular weight polyethylene implants containing GnRH attached to multiple antigenic peptides (MAP) or to covalent dendrimer peptides loaded with nanoparticles of polyanhydric co-polymers resembling bars have been developed. Upon implantation in $\mathrm{C} 3 \mathrm{HeB} / \mathrm{FeJ}$ mice, B and T immune responses were induced for 41 weeks but failed to produce infertility (57).

The utilization of self-replicating releasing systems based on non-pathogenic bacterial or viral vectors, such as lactobacillus, vaccinia viruses, myxoma or murine cytomegalovirus, etc., to design oral or oral-nasal vaccines to control fertility for a long period is appealing, due to their inter-species specificity and their capacity to replicate in the host. A review of Cross et al (58) tackles preclinical results of immunization of different species with candidates based on recombinant viral and bacterial vectors expressing different ZP antigens administered through various routes, including orally.

The use of the so-called recombinant adeno-associated viruses (AAV) has been evaluated to design of vaccines to control fertility. This is a group of single-chain DNA viruses, from vertebrates, belonging to family Parvoviridae whose genome (surrounded by a non-envelope capsid) only has two genes: rep (replication, integration), and cap (structural), as well as transgenic and regulating sequences flanked by two inverted terminal repeats. The integration frequency of these nonautonomous systems is very high, but they cannot replicate unless there is an infection with adenovirus or other viruses. Their advantage is that they can be expressed in non-dividing cells for a long time. The main disadvantage of these systems is the heterogeneity of the auto-immune response caused by low-level transgene expression, which hinders effective presentation of the antigen to the immune system. For instance, in a recent study mice of both sexes were inoculated intramuscularly with 109-1011 AAV particles expressing a recombinant anti-GnRH antibody; only the ones that received the highest dose witnessed infertility for 52 weeks (59). Additionally, the administration route, the risk of affecting nontarget species, and their irreversible effects are significant downsides. 
In our point of view, the development of edible formulations that minimize the animal handling could be the turning point for the massive use of immunocontraception in veterinary practice. In turn, antigenic composition of vaccines will vary according to needs; the immunocastration, contraception in females or fertility induction. For instance, GnRHbased vaccines will be of choice for fertility control in livestock systems and stray animal populations, as they suppress the sexual and aggressive behavior of species, facilitating their management. However, to controlling fertility of wildlife species, where their survival depends on physical performance, the maintenance of rituals associated with reproduction and dominance as well as the social structure of herds, vaccination of the females against sperm proteins could be the best option. The control of fertility in pets is another very complex research field, where the search of solutions satisfying the owners, breeders and guarantee animal welfare, is required, thus demanding vaccines with a high safety profile and long-lasting, reversible effects.

\section{CONCLUSIONS}

The application of immunological methods to control fertility is spreading in common veterinary practice, contributing a reduction in animal suffering. However, their use is not exempt from ethical issues because of limit the natural behavior of species. Hence, it is important to design on new products adjusted to each species' habitat and needs, which poses new challenges to researchers.

Considering on-going research, the problems observed in these vaccines in terms of specificity, heterogeneity and duration of the immunological response, the utilization of multiple doses and administration routes depending on habitat diversity, the requirements of animal welfare and handling, and high costs, might be solved in the near future. Nevertheless, in the application of the new products in veterinary medicine practice there should prevail a preservationist approach toward the protection of ecosystems and ensure the existing balance and welfare among species as the only way to prolong life on the planet.

\section{Conflicts of interest}

The authors declare no conflicts of interest.

Funding: No public or private organization has provided funds to support this research and article.

\section{REFERENCES}

1. Needham T, Lambrechts H, Hoffman LC. Castration of male livestock and the potential of immunocastration to improve animal welfare and production traits: Invited Review. S Afr J Anim Sci. 2017; 47(6):731-742. https://dx.doi. org/10.4314/sajas.v47i6.1

2. Rault JL, Lay DC Jr., Marchant-Forde JN. Castration induced pain in pigs and other livestock. Appl Anim Behav Sci. 2011; 135:214-225. https://dx.doi.org/10.1016/j.applanim.2011.10.017

3. Mallory DA, Nash JM, Ellersieck MR, Smith MF, Patterson DJ. Comparison of long-term progestin-based protocols to synchronize estrus before fixed-time artificial insemination in beef heifers. Anim. Sci. 2011; 89:1358-1365. https:// dx.doi.org/10.2527/jas.2010-3694

4. Báez G, Grajales H. Anestro post parto en ganado bovino en el trópico. Rev MVZ Cordoba. 2009; 14(3):1867-1875 https://doi.org/10.21897/rmvz.347

5. ACC\&D. Contraception and fertility control in dogs and cats: A report of the alliance for contraception in dogs and cats. 5. Marketing overview and issues. Alliance for Contraception in Cats \& Dogs - ACC\&D. 2013. https://www. acc-d.org/docs/default-source/Resource-Library-Docs/accd-e-book.pdf?sfvrsn=0 
6. Candek-Potokar M, Skrlep M, Batorek Lukac N. Raising entire males or immunocastrates - outlook on meat quality. Procedia Food Sci. 2015; 5:30-33. https://doi.org/10.1016/j.profoo.2015.09.008

7. European Commission. European declaration on alternatives to surgical castration of pigs. [Internet]. 2018. [access January 2019]. URL available at: https://ec.europa.eu/food/sites/food/files/animals/docs/aw prac farm pigs cast-alt declaration en.pdf

8. PIGCAS. Report on recommendations for research and policy support. Deliverable D4.1 of the EU project PIGCAS: attitude, practices and state of the art regarding piglet castration in Europe. [Internet]. Institut National De La Recherche Agronomique: Francia; 2009. URL available at: https://cordis.europa.eu/project/id/43969/de

9. Han X, Zhou Y, Zeng Y, Sui F, Liu Y, Tan Y, Cao X, Du X, Meng F, Zeng X._Effects of active immunization against GnRH versus surgical castration on hypothalamic-pituitary function in boars. Theriogenology. 2017; 97:89-97. https:// doi.org/10.1016/j.theriogenology.2017.04.038

10. Aluwé M, Vanhonacker F, Millet S, Tuyttens AM. Influence of hands-on experience on pig farmers' attitude towards alternatives for surgical castration of male piglets. Res Vet Sci. 2015; 103:80-86. https://doi.org/10.1016/j. rvsc.2015.09.019

11. De Roest K, Montanari C, Fowler T, Baltussen, W. Resource efficiency and economic implications of alternatives to surgical castration without anaesthesia. Animal. 2009; 3(11):1522-1531. https://doi.org/10.1017/ $\underline{\mathrm{S} 1751731109990516}$

12. Meeusen ENT, Walker J, Peters A, Pastoret PP, Jungersen G. Current status of veterinary vaccines. Clin Microbiol Rev. 2007; 20(3):489-510. https://doi.org/10.1128/CMR.00005-07

13. Gupta SK, Shrestha A, Minhas V. Milestones in contraceptive vaccines development and hurdles in their application. Hum Vaccin Immunother. 2014; 10(4):911-925. https://doi.org/10.4161/hv.27202

14. Gupta SK, Bhandari B, Shrestha A, Biswal BK, Palaniappan C, Malhotra SS, Gupta N. Mammalian zona pellucida glycoproteins: structure and function during fertilization. Cell Tissue Res. 2012; 349:665-678. https://doi. org/10.1007/s00441-011-1319-y

15. Bechert US, Fraker MA. Twenty Years of SpayVac ${ }^{\circledR}$ Research: Potential Implications for Regulating Feral Horse and Burro Populations in the United States. HUM-WILDL INTERACT. 2018; 12(1):Article13. https://doi.org/10.26077/ q4yh-6m43

16. Roelle JE, Germanie SS, Kene AJ, Cade BS. Efficacy of SpayVac as a Contraceptive in Feral Horses. Wildl Soc Bull. 2017; 41(1):107-115. https://doi.org/10.1002/wsb.729

17. Rutberg AT, Naugle RE, Turner JW, Fraker MA, Flanagan DR. Field testing of single-administration porcine zona pellucida contraceptive vaccines in white-tailed deer (Odocoileus virginianus). Wildl Res. 2013; 40(4):281-288. https://doi.org/10.1071/WR12117

18. Rutberg AK, Grams JW, Turner Jr, Hopkins H. Contraceptive efficacy of priming and boosting doses of controlledrelease PZP in wild horses. Wildl Res. 2017; 44(2):174-181. https://doi.org/10.1071/WR16123

19. Joonè CJ, Schulman ML and Bertschinger HJ. Ovarian dysfunction associated with zona pellucidabased immunocontraceptive vaccines. Theriogenology. 2017; 89:329-337. https://doi.org/10.1016/j. theriogenology.2016.09.018

20. Mohammad I, Khilwani B, Ansari AS, Lohiya NK. Contraceptive vaccines: Implications in male and female fertility regulation. In: SK Gupta, NK Lohiya (ed). Molecular Medicine: Bench to bedside and beyond. First Edition. Indian Society for Study of Reproduction and Fertility; 2018.

21. Hampton JO, Hyndman TH, Barnes A, Collins T. Is Wildlife Fertility Control Always Humane? Animals. 2015; 5:10471071. https://doi.org/10.3390/ani5040398 
22. Goldberg E, Shelton JA. Immunologic properties of LDH-C4 for contraceptive vaccine development. In: Zatuchni GI, Goldsmith A, Sciarra JJ, Spieler J (eds). Male Contraception Advances and Future Prospects. Harper and Row: Philadelphia; 1986.

23. Primakoff P, Lathrop W, Woolman L, Cowan A, Myles D. Fully effective contraception in male and female guinea pigs immunized with the sperm protein PH-20. Nature. 1988; 335:543-546. https://doi.org/10.1038/335543a0

24. Naz RK, Alexander NJ, Isahakia M, Hamilton MD. Monoclonal antibody to a human sperm membrane glycoprotein that inhibits fertilization. Science. 1984; 225:342-344. https://doi.org/10.1126/science.6539947

25. Cheema R, Vashishat N, Bansal A, Bakhri G, Gandotra V. Immuno-contraceptive potential of sperm specific LDHC $_{4}$ and SPAM-1 (PH-20) sub units in dog. Open J Anim Sci. 2012; 2:265-280. https://doi.org/10.4236/ojas.2012.24037

26. Cheema RS, Vashishat N, Bansal AK, Gandotra VK. Mutual interaction of dog sperm LDHC, PH-20, actin and tubulin proteins and their immunocontraceptive potential in bitches. Indian J Anim Res. 2015; 49(4):461-469. https://doi. org/10.5958/0976-0555.2015.00040.0

27. Tollner T, Overstreet J, Branciforte D, Primakoff P. Immunization of female cynomolgus macaques with a synthetic epitope of sperm-specific lactate dehydrogenase results in high antibody titers but does not reduce fertility. Mol Reprod Dev. 2002; 62:257-264. https://doi.org/10.1002/mrd.10063

28. Moudgal NR, Jeyakumar M, Krishnamurthy HN, Sridhar S, Krishnamurthy H, Martín F. Development of male contraceptive vaccine- a perspective. Hum Reprod Update. 1997; 3(4):335-346. https://doi.org/10.1093/ humupd/3.4.335

29. Cohoreau C, Klett D, Combarnous Y. Structure - function relationships of glycoproteins hormones and their subunits' ancestors. Front Endocrinol (Lausanne). 2015; 6:26. https://doi.org/10.3389/fendo.2015.00026

30. Kumar TR, Wang Y, Lu N, Matzuk MM. Follicle stimulating hormone is required for ovarian follicle maturation but not male fertility. Nat Genet. 1997; 15:201-204. https://doi.org/10.1038/ng0297-201

31. Yang L-H, Li J-T, Yan P, Liu H-L, Zeng S-Y, Wu Y-Z, et al. Follicle-stimulating hormone receptor (FSHR)-derived peptide vaccine induced infertility in mice without pathological effect on reproductive organs. Reprod Fertil Dev. 2011; 23:544-550. https://doi.org/10.1071/RD10142

32. Maggi R. Physiology of gonadotropin-releasing hormone (GNRH): beyond the control of reproductive functions. MOJ Anat Physiol. 2016; 2(5):150-154. https://doi.org/10.15406/mojap.2016.02.00063

33. Talwar P. Immunobiology of gonadotropin-releasing hormone. J Steroid Biochem Mol Biol. 1985; 23(5):795-800. https://doi.org/10.1016/s0022-4731(85)80016-9

34. Ferro VA, Stimson WH. Effects of adjuvant, dose and carrier pre-sensitization on the immunization efficacy of a GnRH analogue. Drug Des Discov. 1996; 14(3):179-195. https://www.ncbi.nlm.nih.gov/pubmed/9017362

35. Giri DK, Jayaraman S, Neelaram GS, Jayashankar R, Talwar GP. Prostatic hypoplasia in bonnet monkeys following immunization with semi synthetic anti-LHRH vaccine. Exp Mol Pathol. 1991; 54(3):255-264. https://doi. org/10.1016/0014-4800(91)90035-v

36. Hoskinson RM, Rigby RDG, Mattner PE, Huynh VL, D’Occhio M, Neish A, et al. Vaxstrate; An anti-reproductive vaccine for cattle. Aust J Biotechnol. 1990; 4(3):166-170. http://hdl.handle.net/102.100.100/255038?index=1

37. Zamaratskaia G, Krøyer Rasmussen M. Immunocastration of male pigs - situation today. International 58th Meat Industry Conference "Meat Safety and Quality: Where it goes?" Procedia Food Sci. 2015; 5:324-327. https://doi. org/10.1016/j.profoo.2015.09.064

38. Hernández-García FI, Duarte JL, Pérez MA, Raboso C, del Rosario AI, Izquierdo M. Successful long-term pre-pubertal immunocastration of pure bred Iberian gilts reared in extensive systems. Acta Agric. Slov. 2013; (Suppl 4):123-126. http://aas.bf.uni-lj.si/zootehnika/supl/4-2013/PDF/4-2013-123-126.pdf 
39. Dalmau A, Velarde A, Rodríguez P, Pedernera C, Lionch P, Fäbrega E, et al. Use of anti-GnRF vaccine to suppress estrus in cross - bred Iberian female pigs. Theriogenology. 2015; 84:342-347. https://doi.org/10.1016/j. theriogenology.2015.03.025

40. Amatayakul - Chantler S, Hoe F, Jackson JA, Roca RO, Stegner JE, King V,et al. Effects on performance and carcass and meat quality attributes following immunocastration with the gonadotropin releasing factor vaccine Bopriva or surgical castration of Bos indicus bulls raised on pasture in Brazil. Meat Sci. 2013; 95(1):78-94. https://doi. org/10.1016/j.meatsci.2013.04.008

41. Amatayakul - Chantler S, Jackson JA, Stegner JE, King V, Rubio LMS, Howard R, et al. Immunocastration of Bos indicus $\times$ Brown Swiss bulls in feedlot with gonadotropin-releasing hormone vaccine Bopriva provides improved performance and meat quality. J Anim Sci. 2012; 90:3718-3728. https://doi.org/10.2527/jas.2011-4826

42. Miller, Lowell A.; Rhyan, Jack; and Killian, Gary, GonaCon TM, a Versatile GnRH Contraceptive for a Large Variety of Pest Animal Problems. USDA National Wildlife Research Center - Staff Publications. 2004. https://digitalcommons. unl.edu/icwdm_usdanwrc/371

43. Ülker H, Yilmaz A, Karakuş F, Yörük, M, Budağ C, De Avila D, et al. LHRH Fusion Protein Immunization Alters Testicular Development, Ultrasonographic and Histological Appearance of Ram Testis. Reprod Domest Anim. 2009; 44:593599. https://doi.org/10.1111/j.1439-0531.2007.01024.X

44. Kiyma Z, Adams TE, Hess BW, Riley ML, Murdoch WJ, Moss GE. Gonadal function, sexual behaviour, feedlot performance, and carcass traits of ram lambs actively immunized against GnRH. J Anim Sci. 2000; 78(9):2237-2243. https://doi.org/10.2527/2000.7892237x

45. Junco BJA, Reyes AO, Bover FEE, Fuentes AF, Pimentel VE, Basulto BR, et al. Pharmaceutical Composition Using Gonadotropin-Releasing Hormone (GNRH) Combined Variants as Immunogen. [Patent No. 9364524] International application published under the patent cooperation treaty (PCT). 2008. URL Available in: http://www. freepatentsonline.com/8999931.html

46. Fuentes F, Junco J, Calzada L, López Y, Pimentel E, Basulto Baker R, et al. Effect of a GnRH vaccine formulation on testosterone concentrations and reproduction in adult male rats. Biotecnol Apl. 2014; 31(3):222-227. http://scielo. sld.cu/scielo.php?script=sci arttext\&pid=S1027-28522014000300005\&lng=es

47. Fuentes F, Junco JA, Bover E, Calzada L, López Y, Castro MD, Pimentel E, Basulto R, et al. Very Small Size Proteoliposomes (VSSP) and Montanide combination enhance the humoral immuno response in a GnRH based vaccine directed to prostate cancer. Vaccine. 2012; 30: 6595- 6599. https://doi.org/10.1016/j.vaccine.2012.08.020

48. Aguilar FF, Barranco JJ, Aguilera LC, Fuentes EB, Serradelo Leal JA, López EH, et al. The influence of different peptide combinations to increase the immunogenicity of the Gonadotrophin Releasing Hormone Vaccine for prostate cancer treatment. J Exp Ther Oncol. 2017; 12(2):87-94. https://europepmc.org/article/med/29161775

49. Rosenfield DA, Schilbach Pizzuto C. Wildlife population control - reproductive physiology under the influence of contraceptive methods in mammalian wildlife, with emphasis on immunocontraception: the best choice? A literature review. Braz J Vet Res Anim Sci. 2018; 55(1):1-16. https://doi.org/10.11606/issn.16784456.bjvras.2018.129431

50. Ransom JI, Powers JG, Garbe HM, Oehler MW, NettTM, Baker DL. Behavior of feral horses in response to culling and GnRH immunocontraception. Appl Anim Behav Sci. 2014; 157:81-92. https://doi.org/10.1016/j.applanim.2014.05.002

51. Gupta S, Jain A, Chakraborty M, Sahni JK, Ali J, Dang S. Oral delivery of therapeutic proteins and peptides: a review on recent developments. Drug Deliv. 2013; 20(6):237-246. https://doi.org/10.3109/10717544.2013.819611

52. Hajam IA, Dar PA, Won G, Lee JH. Bacterial ghosts as adjuvants: mechanisms and potential. Vet Res. 2017 ; $48(1): 37$. https://doi.org/10.1186/s13567-017-0442-5

53. Varamini P, Rafiee A, Giddam AK, Mansfeld FM, Steyn F, Toth I. Development of New Gonadotropin-Releasing Hormone-Modified Dendrimer Platforms with Direct Antiproliferative and Gonadotropin Releasing Activity. J Med Chem. 2017. 60(20):8309-8320. https://doi.org/10.1021/acs.jmedchem.6b01771 
54. Moradi SV, Hussein WM, Varamini P, Simerska P, Toth I. Glycosylation, an effective synthetic strategy to improve the bioavailability of therapeutic peptides. Chem Sci. 2016; 7:2492-2500. https://doi.org/10.1039/C5SC04392A

55. Siel D, Vidal S, Carvallo F, Sevilla R, Lapierre L, Paredes R, et al. Effectiveness of an immunocastration vaccine formulation to reduce the gonadal function in female and male mice bTh1/Th2 immune response. Theriogenology. 2016; 86:1589-1598. http://dx.doi.org/10.1016/j.theriogenology.2016.05.019

56. Sharma S, McDonald I, Miller L, Hinds LA. Parenteral administration of GnRH constructs and adjuvants: Immune responses and effects on reproductive tissues of male mice. Vaccine. 2014; 32:5555-5563. http://dx.doi. org/10.1016/j.vaccine.2014.07.075

57. Schaut RG, Brewer MT, Hostetter JM, Mendoza K, Vela - Ramírez JE, Kelly SM et al. A single dose polyanhydride-based vaccine platform promotes and maintains anti-GnRH antibody titers. Vaccine. 2018; 36:1016-1023. https://doi. org/10.1016/j.vaccine.2017.12.050

58. Cross ML, Zheng T, Duckworth JA, Cowan PE. Could recombinant technology facilitate the realization of a fertilitycontrol vaccine for possums?. New Zeal J Zool. 2011; 38(1):91-111, https://doi.org/10.1080/03014223.2010.541468

59. Hay BA, Li J, Guo M. Vectored gene delivery for lifetime animal contraception: Overview and hurdles to implementation. Theriogenology. 2018; 112:63-74. https://doi.org/10.1016/j.theriogenology.2017.11.003 